\title{
IMPROVEMENT OF THE BIOCHEMICAL METHANE POTENTIAL OF FOOD WASTE BY MEANS OF ANAEROBIC CO-DIGESTION WITH SWINE MANURE
}

\author{
L. M. Cárdenas-Cleves ${ }^{1}$, L. F. Marmolejo-Rebellón ${ }^{1}$ and P. Torres-Lozada ${ }^{1 *}$ \\ ${ }^{1}$ Escuela de Ingeniería de los Recursos Naturales y del Ambiente (Study and Control of Environmental Pollution Reseach Group), \\ Universidad del Valle, Calle 13 \# 100-00, Cali, Colombia.
}

(Submitted: June 2, 2017 ; Revised: November 17, 2017 ; Accepted: December 26, 2017)

\begin{abstract}
Food waste (FW) has potential for use by means of anaerobic digestion (AD). However, some characteristics of FW affect process stability and methane $\left(\mathrm{CH}_{4}\right)$ production. Using biochemical methane potential (BMP) tests, this study assessed the improvement of $\mathrm{CH}_{4}$ production and hydrolysis of $\mathrm{FW}$ by means of anaerobic co-digestion (AcoD) with swine manure (SM). Different FW:SM ratios were studied under conditions with (WN) and without (NN) nutrients. The highest $\mathrm{CH}_{4}$ production was obtained for the FW:SM 60:40 ratio in the WN and $\mathrm{SN}$ conditions with values of 72.87 and $62.83 \mathrm{~mL} \mathrm{CH}_{4} \mathrm{~g} \mathrm{VS}^{-1}$, respectively. This showed that AcoD of FW with SM presented synergistic effects, since increases of 27 (WN) and 13\% (NN) were obtained in comparison with the mono-digestion of FW. There was also an improvement in the process stability $(\alpha$ index $>$ 0.7), but there were no favorable effects with respect to the hydrolysis of FW.

Keywords: Anaerobic co-digestion; Food waste; Hydrolysis; Substrate ratios; Swine manure.
\end{abstract}

\section{INTRODUCTION}

According to the Food and Agriculture Organization of the United Nations (FAO), every year 1.3 billion tons of food waste $(\mathrm{FW})$ are generated worldwide (FAO, 2011). Such FW represents the greatest component of municipal solid waste, accounting for $50 \%$ of the waste in developed countries and between $50-60 \%$ of the waste in developing countries (Thi et al., 2015). FW is of special interest because more than $95 \%$ of such material ends up in dumps and landfills, where it is converted to materials with a high polluting potential (Schirmer et al., 2014; Chen et al., 2017). However, the high moisture content (70-90\%) and organic matter of FW favor its use by means of anaerobic digestion (AD) (Zhang et al., 2007; Sitorus et al., 2013).

The $\mathrm{AD}$ of $\mathrm{FW}$ can affect methane $\left(\mathrm{CH}_{4}\right)$ production and the process stability due to acid $\mathrm{pH}$, the lack of bicarbonate alkalinity, the accumulation of volatile fatty acids (VFAs) and the deficiency of some required nutrients, especially of metals such as nickel (Ni), cobalt (Co) and molybdenum (Mo), which are essential for the enzymes involved in $\mathrm{CH}_{4}$ production (Facchin et al., 2013). One of the strategies to improve these deficiencies in the AD of FW is anaerobic codigestion (AcoD), which consists of mixing FW with other organic substrates that have complementary characteristics. The most used substrates in the AcoD of FW are domestic sewage sludge and agroindustrial wastes; these substrates include animal manure, particularly swine manure (SM) (Mata-Alvarez et al., 2014), which increased generation is due to the growth of this economic sector (MacLeod et al., 2013).

Generally, SM is characterized by low Biochemical Methane Potential (BMP) and low $\mathrm{C} / \mathrm{N}$ ratio, which can inhibit methanogenic archaea (Mata-Alvarez

\footnotetext{
* Corresponding author’s e-mail: patricia.torres@correounivalle.edu.co
} 
et al., 2014). However, it has high buffer capacity and nutrient content, which are complementary characteristics to FW. According to Tian et al. (2015) there are few studies that evaluate the AcoD of these two residues and additionally it is necessary to establish the most appropriate FW:SM ratio, that allows one to obtain synergic effects such as improvement in the stability of the process, greater $\mathrm{CH}_{4}$ production, balance of nutrients and favorable effects on the hydrolysis, considered the limiting stage in the $\mathrm{AD}$ of these residues (Koch y Drewes, 2014). In light of the above, this study evaluated the AcoD as a strategy for the improvement of $\mathrm{CH}_{4}$ production and the hydrolysis of FW by incorporating $\mathrm{SM}$ as a co-substrate.

\section{MATERIALS AND METHODS}

\section{Characterization of Substrates and Inoculum}

Substrates - FW was collected from the restaurant of the Universidad del Valle (Cali-Colombia), where approximately 2.4 tons of FW are generated on a weekly basis. The substrates were separated, considering the physical composition and the physicochemical characteristics of the unprocessed FW generated in a city that carries out source separation and selective collection (Oviedo-Ocaña et al., 2017). The FW composition was $56 \%$ bananas and tubers, $24 \%$ citric fruits, $13 \%$ greens, legumes and vegetables and $7 \%$ non-citric fruits. Mechanical crushing of the FW was performed to obtain a particle size equal to or less than $10 \mathrm{~mm}$, as recommended by Raposo et al. (2012). SM was obtained from a slaughterhouse in Valle de Cauca (Colombia). Both substrates were characterized according to the following parameters: moisture (\%), $\mathrm{pH}$ (units), total alkalinity (TA) and bicarbonate alkalinity (BA) $\left(\mathrm{g} \mathrm{CaCO}_{3} \mathrm{~L}^{-1}\right)$, VFAs $\left(\mathrm{g} \mathrm{HAc} \mathrm{L}^{-1}\right)$, chemical oxygen demand (COD): total and filtered ( $\mathrm{g}$ $\left.\mathrm{O}_{2} \mathrm{~L}^{-1}\right)$, total solids (TS) $\left(\mathrm{g} \mathrm{L}^{-1}\right)$, volatile solids (VS) $\left(\mathrm{g} \mathrm{L}^{-1}\right)$, total nitrogen $(\mathrm{TN})\left(\mathrm{g} \mathrm{L}^{-1}\right)$, total phosphorus (TP) $\left(\mathrm{g} \mathrm{L}^{-1}\right)$, nickel $(\mathrm{Ni})\left(\mathrm{mg} \mathrm{L}^{-1}\right)$, cobalt $(\mathrm{Co})\left(\mathrm{mg} \mathrm{L}^{-1}\right)$ and molybdenum (Mo) (mg L-1) (ICONTEC, 2009; ICONTEC, 2011 and APHA et al., 2012).

Inoculum - Sludge was collected from the anaerobic digester of a municipal wastewater treatment plant (WWTP), which operates with a complete mixture in the mesophilic range $\left(35^{\circ} \mathrm{C}\right)$. The physicochemical characterization of the inoculum was carried out by means of $\mathrm{pH}, \mathrm{TA}$ and $\mathrm{BA}, \mathrm{VFA}, \mathrm{TS}$ and VS measurements (APHA et al., 2012). Additionally, the specific methanogenic activity (SMA) (g $\mathrm{COD}_{\mathrm{CH} 4}\left(\mathrm{~g} \mathrm{VSS} \mathrm{d}^{-1}\right)$ ) was determined, following the recommendations of Soto et al. (1993).

\section{Description of the Biochemical Methane Potential tests}

Experimental unit - The OxiTop ${ }^{\circledR}$ system (WTW, Giessen, Germany), based on the manometric method, was used in the Biochemical Methane Potential (BMP) tests. The working volume was $200 \mathrm{~mL}$, whereas the free volume was $50 \mathrm{~mL}$.

The OxiTop ${ }^{\circledR}$ system allows the direct measurement of the $\mathrm{CH}_{4}$ generated by means of $\mathrm{CO}_{2}$ sequestration. Here, $4 \mathrm{NaOH}$ pellets were added to each reactor based on the results previously obtained. In this condition, chromatographic tests indicated that $99 \%$ of the biogas generated corresponded to $\mathrm{CH}_{4}$ (Parra et al., 2015).

Experimental and Operational Conditions - BMP tests were performed in the mesophilic temperature range, thus ensuring a temperature of $35 \pm 0.1^{\circ} \mathrm{C}$ inside the Thermostat cabinet TS 606-G/2-i (WTW, Giessen, Germany); $\mathrm{pH}$ was adjusted to 7 units using a sodium bicarbonate solution $\left(\mathrm{NaHCO}_{3}\right)(4 \%)$; agitation was manual and intermittent and was performed 3 times a day before measuring the pressure. The incubation period was 30 days, after which $\mathrm{CH}_{4}$ production stabilized because the pressure did not vary by more than $5 \mathrm{hPa}$ (Pabón et al., 2012).

A control (inoculum and distilled water) was included in all BMP tests to determine the $\mathrm{CH}_{4}$ generated by the residual organic matter present in the inoculum and by endogenous metabolism, the value of which was subtracted from the $\mathrm{CH}_{4}$ produced in each reactor. The control parameters that were measured at the end of each test were $\mathrm{pH}, \mathrm{TA}$ and BA. Furthermore, the alpha index $(\alpha)$ that corresponded to the BA and TA ratio was calculated to analyze the stability of the process (Pérez and Torres, 2011). Additionally, the $\mathrm{CH}_{4}$ volume under standard conditions was determined using the equations suggested by Parra et al. (2015).

\section{BMP tests: Influence of the Substrate Ratio and Nutrient Addition}

BMP tests were performed using a substrate/ inoculum $(\mathrm{S} / \mathrm{I})$ ratio of $1 \mathrm{~g} \mathrm{VS}_{\text {Substrate }} / \mathrm{g} \mathrm{VS}_{\text {Inoculum, }}$ following the recommendations of Owen et al. (1979) and Labatut et al. (2011). The inoculum (I) concentration was $1.5 \mathrm{~g} \mathrm{VS} \mathrm{L}^{-1}$ (Soto et al., 1993), whereas the VS concentrations of the substrates (S) were different from the ranges assessed in previous studies (Adelard et al., 2015; Tian et al., 2015). Each test was performed under conditions with (WN) and without (NN) nutrients. In the first case, the solution recommended by Aquino et al. (2007), Angelidaki et al. (2009) and Torres and Perez (2010) was added.

Table 1 shows the experimental design of the BMP tests, which were conducted in triplicate. The BMP for each substrate ratio in both nutrient conditions were 
Table 1. BMP test to evaluate the influence of the substrate ratios and nutrient addition.

\begin{tabular}{|c|c|c|c|c|c|}
\hline \multirow{2}{*}{ Reactor } & \multicolumn{2}{|r|}{ FW } & \multicolumn{2}{|r|}{$\mathbf{S M}$} & \multirow{2}{*}{$\begin{array}{c}I \\
\left(\mathrm{~g} \mathrm{VS} \mathrm{L}^{-1}\right)\end{array}$} \\
\hline & $\%$ & $\left(g_{V S ~ L}-1\right)$ & $\%$ & $\left(g_{V S ~ L}-1\right)$ & \\
\hline 1 & 100 & 1.50 & 0 & 0 & 1.50 \\
\hline 2 & 80 & 1.20 & 20 & 0.30 & 1.50 \\
\hline 3 & 60 & 0.90 & 40 & 0.60 & 1.50 \\
\hline 4 & 50 & 0.75 & 50 & 0.75 & 1.50 \\
\hline 5 & 40 & 0.60 & 60 & 0.90 & 1.50 \\
\hline 6 & 20 & 0.30 & 80 & 1.20 & 1.50 \\
\hline 7 & 0 & 0 & 100 & 1.50 & 1.50 \\
\hline
\end{tabular}

compared in order to verify the possible contribution of these elements by the SM, determining the COD:N:P ratio and the concentration of trace elements essential for AD of RA such as Ni, Co and Mo (Uemura, 2010, Banks et al., 2012, Facchin et al., 2013).

In order to determine the possible synergistic or antagonistic effects of the substrate ratios assessed under $\mathrm{WN}$ and $\mathrm{NN}$ conditions, the difference between the experimental BMP (obtained from the substrate ratio and nutrient condition) and the weighted BMP $\left(\mathrm{BMP}_{\mathrm{w}}\right)$ was calculated using Equation 1 (Labatut et al., 2011). When the difference (BMP- $\left.\mathrm{BMP}_{\mathrm{w}}\right)$ was positive and higher than the value of the weighted BMP considering the standard deviations, a synergistic effect was noted; otherwise, the effect was antagonistic.

$B M P_{W}=B M P_{F W} * \% F W+B M P_{S M} * \% S M$

where $\mathrm{BMP}_{\mathrm{w}}$ is the weighted biochemical methane potential, $\mathrm{BMP}_{\mathrm{FW}}$ is the experimental biochemical methane potential obtained in the AD of FW (100:0 ratio), $\% \mathrm{FW}$ is the $\mathrm{FW}$ percentage in the ratio, $\mathrm{BMP}_{\mathrm{SM}}$ is the experimental biochemical methane potential obtained in the AD of SM (0:100 ratio), and \% SM is the SM percentage in the ratio.

\section{Influence of the Substrate Ratio and Nutrient Addition on Hydrolysis}

The first-order kinetic model and modified Gompertz model were used (Equations 2 and 3, respectively). The first model assumes that the hydrolysis of the particulate matter follows first-order kinetics, whereas the second model is based on the premise that $\mathrm{CH}_{4}$ production is proportional to microbial activity (Nielfa et al., 2015; Parra-Orobio et al., 2017).

$$
\begin{aligned}
& B M P=B M P_{\text {max }}\left[1-\exp \left(-k_{h} t\right)\right] \\
& B M P=B M P_{\text {max }} \exp \left\{-\exp \left[\frac{R_{\text {max }} e}{B M P_{\text {max }}}(\lambda-t)+1\right]\right\}
\end{aligned}
$$

where BMP is the biochemical potential of the $\mathrm{CH}_{4}$ accumulated during the test $\left(\mathrm{mL} \mathrm{CH}_{4} \mathrm{~g} \mathrm{VS}^{-1}\right), \mathrm{BMP}_{\max }$ is the potential maximum $\mathrm{CH}_{4}$ production when the time tends to infinity $\left(\mathrm{mL} \mathrm{CH}_{4} \mathrm{~g} \mathrm{VS}^{-1}\right), \mathrm{k}_{\mathrm{h}}$ is the firstorder hydrolysis constant $\left(\mathrm{d}^{-1}\right), \mathrm{t}$ is the test time $(\mathrm{d})$, $\mathrm{R}_{\max }$ is the maximum rate of $\mathrm{CH}_{4}$ production $\left(\mathrm{mL} \mathrm{CH}_{4}\right.$ $\left.\mathrm{d}^{-1} \mathrm{~g} \mathrm{VS}^{-1}\right), \lambda$ is the lag phase (d), and $e$ is the base of natural logarithm $(e=2.718)$.

For the estimation of the values in the first-order kinetic model equations $\left(\mathrm{BMP}_{\max }\right.$ and $\mathrm{k}_{\mathrm{h}}$ ) and the modified Gompertz model equations $\left(\mathrm{BM} \mathrm{P}_{\max }, \mathrm{R}_{\max }\right.$ and $\lambda$ ), the experimental data of the mean BMP and the time for each reactor were used, for which a nonlinear regression was obtained using the LevenbergMarquardt algorithm in $\mathrm{R}$ software i386 3.4.2 (R Foundation $\left.{ }^{\circledR}\right)$. To verify the adjustment of the data to the models, the coefficient of determination $\left(\mathrm{R}^{2}\right)$ and mean squared error (MSE) were determined, as recommended by Kafle and Kim (2013).

Statistical analysis - To assess the influence of the factors (substrate ratio and nutrient addition) on the response variable (BMP), analysis of variance (ANOVA) and Tukey's tests $(\mathrm{p}<0.05)$ were performed, using R software i386 3.4.2 (R Foundation ${ }^{\circledR}$ ).

\section{RESULTS AND DISCUSSION}

\section{Characterization of Substrates and Inoculum}

Table 2 presents the results of the physicochemical characterization of the substrates and inoculum.

FW had a high moisture content because it was mainly composed of fruits and vegetables (Zhang et al., 2007). Such waste degrades easily, thus favoring VFA formation and accumulation (Lü et al., 2012; Sitorus et al., 2013) with a value close to $4 \mathrm{~g} \mathrm{~L}^{-1}$. According to Wang et al. (2009), this concentration can slightly inhibit the AD process. This value coincided with a low $\mathrm{pH}$ (5.17) and the absence of BA.

The values of $\mathrm{COD}_{\text {Total }}$, TS, and VS coincide with those reported by Chu et al. (2008) and showed that FW contained a high organic matter content that was particulate, according to the value obtained for the $\mathrm{COD}_{\text {Filtered }} / \mathrm{COD}_{\text {Total }}$ ratio, which was 0.27 . This can affect the hydrolysis stage of organic matter (Parra et al., 2015). In terms of nutrient content, the $\mathrm{COD}_{\text {Total }}: \mathrm{N}: \mathrm{P}$ ratio (350:5.43:0.59) showed a phosphorus deficiency according to the value recommended by Ye et al. (2015) for the $\mathrm{AD}$ process (350:5:1). Low concentrations of $\mathrm{Ni}, \mathrm{Co}$ and Mo are found, since these present the minimum values reported by Romero-Güiza et al. (2016) to be considered stimulants of the process.

In the case of SM, the $\mathrm{pH}, \mathrm{TA}, \mathrm{BA}$ and VFA values were similar to those reported by Ye et al. (2013) and Rodríguez-Verde et al. (2014). In general, the $\mathrm{pH}$ of SM was almost neutral, and unlike FW, BA accounted for approximately $60 \%$ of the TA, thus showing 
Table 2. Physicochemical characterization of substrates and inoculum.

\begin{tabular}{|c|c|c|c|c|}
\hline Parameter & Unit & *Food Waste (FW) & *Swine Manure (SM) & *Inoculum (I) \\
\hline Moisture ( $\mathrm{n}$ FW, SM, I =4) & $\%$ & $78.53 \pm 6.18$ & $84.62 \pm 8.16$ & N.D \\
\hline $\mathrm{pH}(\mathrm{n}$ FW, SM, I =4) & Units & 5.17 & 7.34 & 7.16 \\
\hline TA (n FW, SM, I =4) & $\mathrm{g} \mathrm{CaCO}_{3} \mathrm{~L}^{-1}$ & $4.21 \pm 3.44$ & $21.06 \pm 9.00$ & $4.22 \pm 0.83$ \\
\hline $\mathrm{BA}(\mathrm{n} \mathrm{FW}, \mathrm{SM}, \mathrm{I}=4)$ & $\mathrm{g} \mathrm{CaCO}_{3} \mathrm{~L}^{-1}$ & - & $12.64 \pm 2.42$ & $2.42 \pm 0.30$ \\
\hline VFAs (n FW, SM, I $=4$ ) & g HAc L ${ }^{-1}$ & $3.65 \pm 0.23$ & $4.65 \pm 0.81$ & $1.54 \pm 0.04$ \\
\hline $\mathrm{COD}_{\text {Total }}(\mathrm{n}$ FW, $\mathrm{SM}=4)$ & $\mathrm{g} \mathrm{O}_{2} \mathrm{~L}^{-1}$ & $80.41 \pm 8.84$ & $576.28 \pm 29.57$ & N.D \\
\hline $\mathrm{COD}_{\text {Filtered }}(\mathrm{n}$ FW, SM $=4)$ & $\mathrm{g} \mathrm{O}_{2} \mathrm{~L}^{-1}$ & $22.03 \pm 2.01$ & $172.00 \pm 2.36$ & N.D \\
\hline $\mathrm{TS}(\mathrm{n}$ FW, SM, I $=4)$ & $\mathrm{g} \mathrm{L}^{-1}$ & $88.31 \pm 6.45$ & $214.88 \pm 0.46$ & $56.98 \pm 0.53$ \\
\hline VS $(\mathrm{n}$ FW, SM, I $=4)$ & $\mathrm{g} \mathrm{L}^{-1}$ & $81.06 \pm 6.95$ & $174.55 \pm 1.27$ & $27.55 \pm 0.21$ \\
\hline $\mathrm{TN}\left(\mathrm{n}_{\mathrm{FW}}, \mathrm{SM}=4\right)$ & $\mathrm{g} \mathrm{L}^{-1}$ & $1.25 \pm 0.18$ & $38.10 \pm 0.20$ & N.D \\
\hline $\mathrm{TP}(\mathrm{n}$ FW, SM $=4)$ & $\mathrm{g} \mathrm{L}^{-1}$ & $0.14 \pm 0.02$ & $3.70 \pm 1.49$ & N.D \\
\hline $\mathrm{Ni}\left(\mathrm{n}_{\mathrm{FW}}=3\right) ;\left(\mathrm{n} \mathrm{SM}_{\mathrm{S}}=1\right)$ & $\mathrm{mg} \mathrm{L}^{-1}$ & $1.93 \pm 1.42$ & 3.14 & N.D \\
\hline $\mathrm{Co}\left(\mathrm{n}_{\mathrm{FW}}=5\right) ;\left(\mathrm{n}_{\mathrm{SM}}=1\right)$ & $\mathrm{mg} \mathrm{L}^{-1}$ & $1.63 \pm 0.90$ & 4.19 & N.D \\
\hline $\operatorname{Mo}\left(\mathrm{n}_{\mathrm{FW}}=3\right) ;\left(\mathrm{n}_{\mathrm{SM}}=1\right)$ & $\mathrm{mg} \mathrm{L}^{-1}$ & $0.33 \pm 0.28$ & 2.31 & N.D \\
\hline SMA & $\mathrm{g} \mathrm{COD}_{\mathrm{CH} 4}\left(\mathrm{~g} \mathrm{VSS} \mathrm{d}^{-1}\right.$ & N.D & N.D & 0.008 \\
\hline
\end{tabular}

*Average values \pm S.D (standard deviation); number of samples (n); N.D: not determined.

potential to contribute buffering capacity to the process. SM exhibited a high organic matter content, as shown by the values for $\mathrm{COD}_{\text {Total }}$, TS and VS, which predominate in particulate form, in accordance with the $\mathrm{COD}_{\text {Filtered }} / \mathrm{COD}_{\text {Total }}$ ratio of 0.30 . The $\mathrm{COD}_{\text {Total }}: \mathrm{N}: \mathrm{P}$ ratio $(350: 23.14: 2.25)$ showed that these elements were not deficient. The concentrations of $\mathrm{Ni}, \mathrm{Co}$ and Mo are in the ranges that favor the process and do not generate inhibition (Romero-Güiza et al. (2016).

With respect to the inoculum, the $\mathrm{pH}, \mathrm{TA}, \mathrm{BA}$, VFA, TS and VS values were within the characteristic ranges for sludge from the anaerobic digesters of WWTPs (Raposo et al., 2006; Cabbai et al., 2013). Additionally, the $\mathrm{pH}$ value was near neutral, and the $\alpha$ index was 0.57 , thus indicating that the inoculum contributed buffering capacity to the process. The VS/ TS ratio (0.48) and the SMA value indicated a low activity of the inoculum compared to the findings of Angelidaki et al. (2009).

\section{BMP tests: Influence of the Substrate Ratio and Nutrient Addition}

Figure 1 compares BMP under $\mathrm{WN}$ and $\mathrm{NN}$ conditions for each FW:SM ratio assessed. Figure 1 shows that the BMP of FW (FW:SM 100:0 ratio) was higher than that of SM (FW:SM 0:100 ratio) under both nutrient conditions. This agrees with the findings of

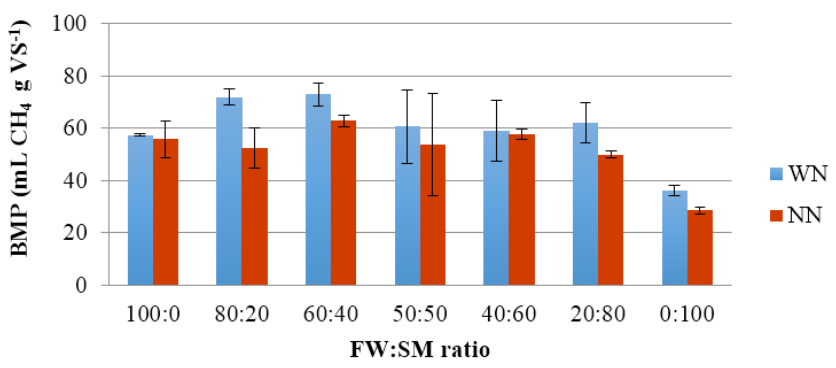

Figure 1. BMP for each substrate ratio and nutrient condition.
Browne et al. (2013) and Mata-Alvarez et al. (2014), who claim that SM presents a low organic content that affects $\mathrm{CH}_{4}$ production. In general, BMP was higher under the $\mathrm{WN}$ condition.

Under the WN condition, and according to the ANOVA and Tukey test $(\mathrm{p}<0.05)$ results, significant differences were found between the substrate ratio FW:SM 60:40 and the other ratios. Additionally, it was noted that the highest BMP values were obtained at the FW:SM 60:40 (72.87 $\left.\mathrm{mL} \mathrm{CH}_{4} \mathrm{~g} \mathrm{VS}^{-1}\right)$ and 80:20 (71.89 $\mathrm{mL} \mathrm{CH} \mathrm{g} \mathrm{VS}^{-1}$ ) ratios. In general, a favorable effect of the AcoD was observed because, when considering the best ratio, a $27 \%$ increase in $\mathrm{CH}_{4}$ production was obtained with respect to the AD of FW (100:0).

Under the NN condition, the FW:SM 60:40 ratio also presented the highest BMP value $\left(62.83 \mathrm{~mL} \mathrm{CH}_{4}\right.$ $\mathrm{g} \mathrm{VS}^{-1}$ ), which coincides with the values reported by Tian et al. (2015), who carried out an AcoD of SM and FW without nutrient addition and found higher $\mathrm{CH}_{4}$ production at the ratios in which $\mathrm{FW}$ was present at a higher proportion. The ANOVA and Tukey test $(p<0.05)$ results showed significant differences between different $\mathrm{FW}: \mathrm{SM}$ ratios. In this regard, SM:FW 60:40 was the best ratio because it increased $\mathrm{CH}_{4}$ production by $13 \%$ with respect to the AD of FW.

Additionally, the statistical analysis indicated that significant differences existed between the conditions assessed, with $\mathrm{NN}$ being the better of the two. To evaluate the effect of the evaluated factors on nutrient requirements, the concentrations of macro (COD ratio: $\mathrm{N}: \mathrm{P})$ and essential micronutrients $(\mathrm{Ni}$, Co and Mo) in each FW:SM ratio under $\mathrm{WN}$ and $\mathrm{NN}$ conditions were determined, the results obtained are presented in Table 3.

Table 3 shows that FW (FW:SM 100:0 ratio) under the $\mathrm{NN}$ condition presented $\mathrm{P}$ deficiency, in contrast to the $\mathrm{WN}$ condition in which the COD:N:P ratio was higher than the recommended (350:5:1) (Ye et al., 2015). However, there was a higher $\mathrm{CH}_{4}$ production 
Table 3. COD:N:P ratio and concentration of micronutrients for each FW:SM ratio under WN and NN conditions.

\begin{tabular}{ccccccccc}
\hline FW:SM & \multicolumn{3}{c}{ WN } & & & & NN & Mo \\
\cline { 2 - 9 } Ratio & COD $_{\text {Total }: \mathbf{N}: P}$ & Ni & Co & Mo & COD $_{\text {Total }: \mathbf{N}: P}$ & Ni & Co & Mo \\
\hline $100: 0$ & $350: 15.52: 2.50$ & 0.044 & 0.055 & 0.532 & $350: 5.43: 0.59$ & 0.031 & 0.006 & 0.037 \\
$80: 20$ & $350: 20.74: 2.54$ & 0.049 & 0.060 & 0.533 & $350: 15.33: 1.52$ & 0.037 & 0.011 & 0.038 \\
$60: 40$ & $350: 22.66: 2.56$ & 0.055 & 0.066 & 0.534 & $350: 18.96: 1.86$ & 0.042 & 0.017 & 0.039 \\
$50: 50$ & $350: 23.23: 2.56$ & 0.057 & 0.068 & 0.535 & $350: 20.03: 1.96$ & 0.045 & 0.019 & 0.039 \\
$40: 60$ & $350: 23.66: 2.56$ & 0.060 & 0.071 & 0.535 & $350: 20.85: 2.03$ & 0.048 & 0.022 & 0.040 \\
$20: 80$ & $350: 24.27: 2.57$ & 0.065 & 0.076 & 0.536 & $350: 22.00: 2.14$ & 0.053 & 0.027 & 0.041 \\
$0: 100$ & $350: 24.68: 2.57$ & 0.071 & 0.081 & 0.537 & $350: 22.78: 2.21$ & 0.058 & 0.032 & 0.042 \\
\hline
\end{tabular}

$\mathrm{COD}_{\text {total }}, \mathrm{N}, \mathrm{P}, \mathrm{Ni}, \mathrm{Mo} \mathrm{y} \mathrm{Co}\left(\mathrm{mg} \mathrm{L}^{-1}\right)$.

in the $\mathrm{WN}$ condition when the $\mathrm{P}$ value was higher than $2.50 \mathrm{mg} \mathrm{L}^{-1}$. Regarding the content of N, at all FW:SM ratios, in both nutrient conditions, an adequate presence of this element was evidenced, so it is possible that the addition of macronutrients in AcoD of FW with SM is not required.

Regarding micronutrients, according to Moestedt et al. (2016) $\mathrm{Ni}$ is required for the synthesis of co-factor F430 involved in methanogenesis. The importance of Co is because it is a structural component of Vitamin B12 that catalyzes methanogenesis (Khanal, 2011) and Mo inhibits sulfatoreductora bacteria and is a cofactor of several enzymes (Matheri et al., 2016). Table 3 shows that Ni concentrations were similar in both nutrient conditions and were close to the lower limit of the range reported as stimulant in the AD process (0.03 and $27 \mathrm{mg} \mathrm{L}^{-1}$ ) (Romero-Güiza et al., 2016). With respect to Co, at all FW:SM ratios evaluated in the $\mathrm{NN}$ condition, limitations of this element were present, because a concentration between 0.03 and 19 $\mathrm{mg} \mathrm{L}^{-1}$ is required to favor the $\mathrm{AD}$ process (RomeroGüiza et al., 2016). Finally, the concentrations of Mo in the NN condition have a stimulating effect $(<0.05$ $\mathrm{mg} \mathrm{L}^{-1}$ ), while in the $\mathrm{WN}$ condition do not present a risk of inhibition (Romero-Güiza et al., 2016).

It has been reported that the addition of micronutrients is essential for $\mathrm{AD}$ of $\mathrm{FW}$ because these present low concentrations (Zhang et al., 2012). In this sense, Facchin et al. (2013) showed that the external addition of micronutrients increased the BMP of FW by 60 to $70 \%$. Additionally, the micronutrients contribution was made through the AcoD with other residues. Nordell et al. (2016) showed that, in the AcoD of FW with SM, the latter provides macro and micronutrients required in the process; however, the external addition of $\mathrm{Ni}$ and $\mathrm{Co}$ reduced the concentration of VFAs and increased the $\mathrm{CH}_{4}$ production by $10 \%$, which could be due to the low bioavailability of these micronutrients in the SM.

The stability of the process was determined by means of different control parameters shown in Table 4.

Table 4 shows that, under WN and NN conditions, the lowest $\alpha$ index was obtained in unmixed food waste (FW:SM 100:0 ratio), whereas in the AcoD with SM, the $\alpha$ index was higher than 0.60 , indicating stable conditions between the degradation of organic matter and VFA consumption by acetogenic microorganisms (Campos, 2001; Labatut and Gooch, 2012). This behavior resulted from the fact that SM contributed bicarbonate alkalinity. This bicarbonate alkalinity provided buffering capacity, thus allowing continuous $\mathrm{pH}$ regulation and system recovery during the process (Flotats et al., 2001).

The existence of synergistic or antagonistic effects for each FW:SM ratio was verified under WN and NN conditions. The results are presented in Table 5.

Table 5 shows the synergistic effect of the AcoD of FW and SM, with the exception of the FW:SM 50:50 ratio under $\mathrm{WN}$ and $\mathrm{NN}$ conditions and the 80:20 ratio under the NN condition, where the effect is unclear, despite the difference between BMP and $\mathrm{BMP}_{\mathrm{w}}$ being positive. This is because $\mathrm{BMP}_{\mathrm{w}}$ was within the standard deviation of the BMP. Such an effect was also reported by Labatut et al. (2011), who indicated that, in this case, it was not possible to establish whether the effect was synergistic or antagonistic. In general, a favorable effect of the AcoD of FW with SM was observed. In

Table 4. Parameters measured after the process under WN and NN conditions.

\begin{tabular}{ccccccccc}
\hline FW:SM & \multicolumn{9}{c}{ WN } & \multicolumn{2}{c}{ NN } & \multicolumn{3}{c}{ TA } & $\boldsymbol{\alpha}$ index \\
\cline { 2 - 9 } Ratio & $\mathbf{p H}$ & BA & TA & $\boldsymbol{\alpha}$ index & pH & BA & TA \\
\hline $100: 0$ & $8.45 \pm 0.04$ & $337.71 \pm 5.23$ & $1163.48 \pm 31.37$ & 0.29 & $8.24 \pm 0.18$ & $207.06 \pm 24.40$ & $414.12 \pm 3.49$ & 0.50 \\
$80: 20$ & $8.04 \pm 0.03$ & $369.75 \pm 3.49$ & $497.93 \pm 3.49$ & 0.74 & $8.32 \pm 0.06$ & $330.31 \pm 34.86$ & $475.75 \pm 62.75$ & 0.69 \\
$60: 40$ & $8.56 \pm 0.23$ & $438.77 \pm 71.46$ & $463.42 \pm 10.46$ & 0.95 & $7.95 \pm 0.01$ & $290.87 \pm 22.66$ & $401.80 \pm 41.83$ & 0.72 \\
$50: 50$ & $7.92 \pm 0.02$ & $313.06 \pm 17.43$ & $436.31 \pm 1.74$ & 0.72 & $7.60 \pm 0.04$ & $256.36 \pm 17.43$ & $337.71 \pm 40.09$ & 0.76 \\
$40: 60$ & $7.93 \pm 0.16$ & $303.20 \pm 19.17$ & $423.98 \pm 27.89$ & 0.72 & $7.81 \pm 0.01$ & $253.90 \pm 34.86$ & $367.29 \pm 27.89$ & 0.69 \\
$20: 80$ & $7.69 \pm 0.02$ & $266.22 \pm 1.74$ & $379.61 \pm 3.49$ & 0.70 & $7.62 \pm 0.06$ & $224.32 \pm 3.49$ & $337.71 \pm 1.74$ & 0.66 \\
$0: 100$ & $7.44 \pm 0.01$ & $189.81 \pm 5.23$ & $285.94 \pm 3.49$ & 0.66 & $7.43 \pm 0.02$ & $197.20 \pm 15.69$ & $340.17 \pm 13.94$ & 0.58 \\
\hline
\end{tabular}

$\mathrm{pH}$ (Unit); BA and TA (mg CaCO $\left.\mathrm{L}^{-1}\right)$; number of assays: 3 . 
Table 5. Synergistic or antagonistic effects of the FW:SM ratio on BMP under WN and NN conditions.

\begin{tabular}{|c|c|c|c|c|c|c|c|c|c|c|}
\hline \multirow{3}{*}{$\begin{array}{c}\text { FW:SM } \\
\text { ratio }\end{array}$} & \multicolumn{5}{|c|}{ WN } & \multicolumn{5}{|c|}{ NN } \\
\hline & \multirow[b]{2}{*}{ BMP } & \multirow[b]{2}{*}{ S.D } & \multirow[b]{2}{*}{$\mathbf{B M P}_{\mathbf{W}}$} & \multirow{2}{*}{\multicolumn{2}{|c|}{$\begin{array}{l}\text { Effect } \\
\text { BMP- } \\
\text { BMP }_{\mathrm{W}}\end{array}$}} & \multirow[b]{2}{*}{ BMP } & \multirow[b]{2}{*}{ S.D } & \multirow[b]{2}{*}{$\mathbf{B M P}_{\mathbf{w}}$} & \multirow{2}{*}{\multicolumn{2}{|c|}{\begin{tabular}{l}
\multicolumn{1}{c}{ Effect } \\
BMP- \\
BMP $_{\mathrm{W}}$
\end{tabular}}} \\
\hline & & & & & & & & & & \\
\hline 100:0 & 57.33 & 0.35 & 57.33 & 0.00 & - & 55.83 & 7.08 & 55.83 & 0.00 & - \\
\hline $80: 20$ & 71.89 & 3.22 & 53.10 & 18.79 & $\mathrm{~S}$ & 52.46 & 7.82 & 50.39 & 2.06 & $*$ \\
\hline $60: 40$ & 72.87 & 4.37 & 48.87 & 24.00 & $\mathrm{~S}$ & 62.83 & 2.12 & 44.95 & 17.87 & $\mathrm{~S}$ \\
\hline $50: 50$ & 60.64 & 14.08 & 46.76 & 13.88 & * & 53.69 & 19.34 & 42.23 & 11.46 & $*$ \\
\hline $40: 60$ & 58.89 & 11.74 & 44.65 & 14.25 & $\mathrm{~S}$ & 57.50 & 1.95 & 39.51 & 17.99 & $\mathrm{~S}$ \\
\hline $20: 80$ & 62.08 & 7.82 & 40.42 & 21.66 & $\mathrm{~S}$ & 49.93 & 1.28 & 34.07 & 15.86 & S \\
\hline $0: 100$ & 36.19 & 2.07 & 36.19 & 0.00 & - & 28.63 & 1.27 & 28.63 & 0.00 & - \\
\hline
\end{tabular}

$\mathrm{BMP}_{\mathrm{w}}$ : weighted biochemical methane potential ( $\left.\mathrm{mL} \mathrm{CH}_{4} \mathrm{~g} \mathrm{VS}^{-1}\right)$; S.D: standard deviation; S: synergistic effect; *: undefined; number of assays: 3.

this sense, the AcoD improved the AD of FW because it contributed important nutrients such as nitrogen and phosphorus for the growth of microorganisms. Furthermore, it contributed buffering capacity to the process by maintaining a stable $\mathrm{pH}$ (Kafle and Kim, 2013; Adelard et al., 2015; Lima et al., 2016).
Influence of the Substrate Ratio and Nutrient Addition on Hydrolysis

Figure 2 and 3 show the graphs with the experimental data and adjusted models under $\mathrm{WN}$ and NN conditions, respectively.
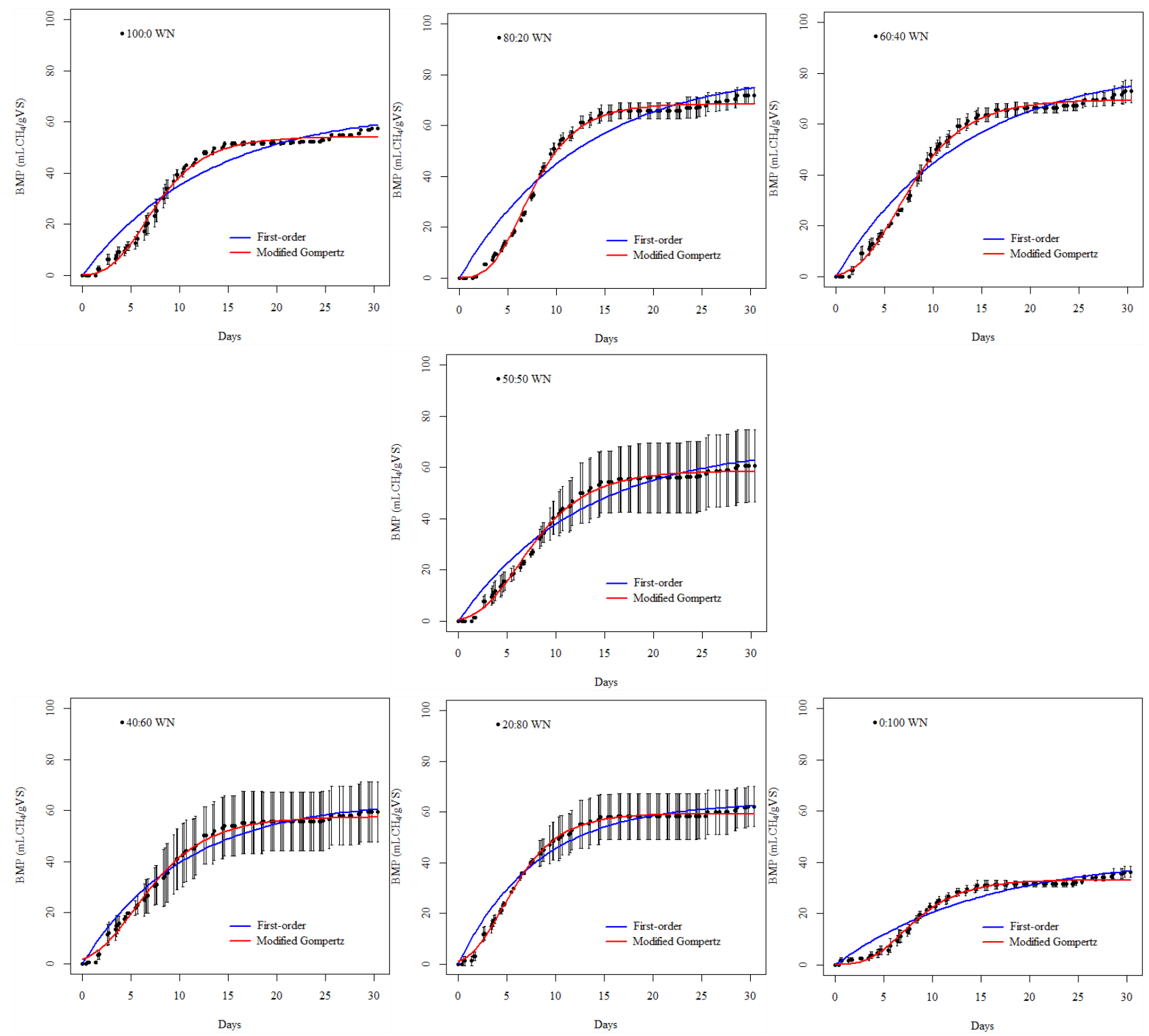

Figure 2. BMP and adjusted First-order and Modified Gompertz models under the WN condition. 

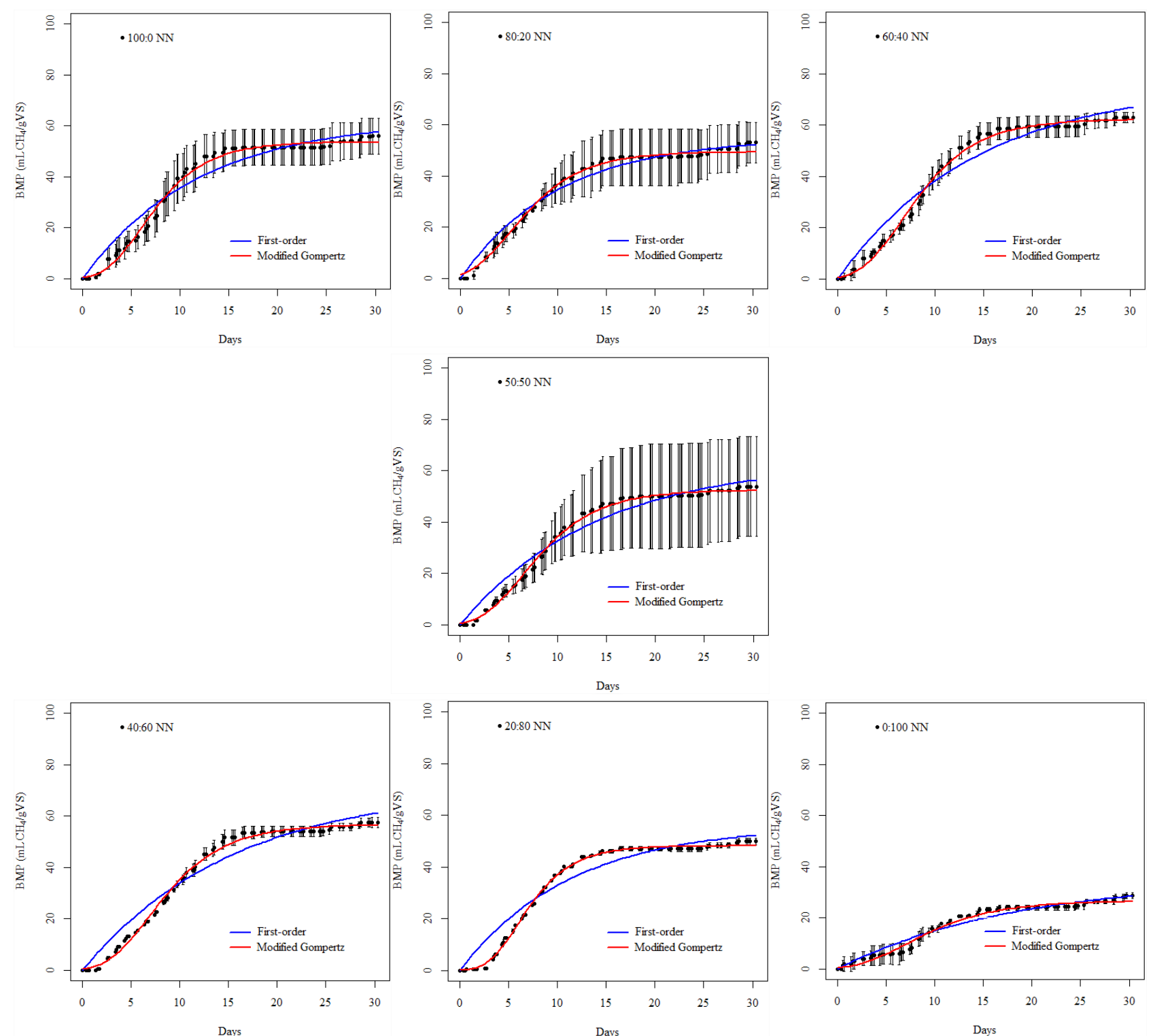

Figure 3. BMP and adjusted First-order and Modified Gompertz models under the NN condition.

Figures 2 and 3 show that, for both nutrient conditions (WN and $\mathrm{NN}$ ), the experimental results presented a better adjustment to the modified Gompertz model because this model takes into account the lag phase that was observed in all BMP curves. On the contrary, the first-order kinetic model was not precise in the representation of the process. However, according to Pagés et al. (2011), the first-order kinetic model provides a useful description of the rate of degradation and the maximum $\mathrm{CH}_{4}$ production.

Tables 6 and 7 show the respective results of the kinetic parameters determined using the first-order and modified Gompertz models for each FW:SM ratio assessed under $\mathrm{WN}$ and $\mathrm{NN}$ conditions.

Table 6. Kinetic parameters for FW:SM ratios under the WN condition.

\begin{tabular}{|c|c|c|c|c|c|c|c|c|c|}
\hline \multirow{2}{*}{$\begin{array}{c}\text { FW:SM } \\
\text { ratio }\end{array}$} & \multicolumn{4}{|c|}{ First-order Kinetics Model } & \multicolumn{5}{|c|}{ Modified Gompertz Model } \\
\hline & $\mathbf{B M P}_{\max }$ & $\begin{array}{c}\mathbf{k}_{\mathbf{h}} \\
\left(\mathbf{d}^{-1}\right)\end{array}$ & $\mathbf{R}^{2}$ & MSE & $\mathbf{B M P}_{\max }$ & $\mathbf{R}_{\max }$ & $\begin{array}{c}\lambda \\
\text { (d) }\end{array}$ & $\mathbf{R}^{2}$ & MSE \\
\hline $100: 0$ & $64.98 \pm 2.35$ & $0.078 \pm 0.006$ & 0.937 & 23.04 & $54.06 \pm 0.28$ & $5.80 \pm 0.15$ & $2.85 \pm 0.12$ & 0.993 & 2.56 \\
\hline $80: 20$ & $82.54 \pm 3.14$ & $0.078 \pm 0.007$ & 0.931 & 42.12 & $68.43 \pm 0.28$ & $7.92 \pm 0.17$ & $3.12 \pm 0.09$ & 0.995 & 2.76 \\
\hline $60: 40$ & $82.94 \pm 2.52$ & $0.077 \pm 0.005$ & 0.955 & 25.54 & $69.46 \pm 0.31$ & $6.48 \pm 0.12$ & $2.22 \pm 0.10$ & 0.995 & 2.58 \\
\hline $50: 50$ & $69.10 \pm 1.99$ & $0.079 \pm 0.005$ & 0.956 & 17.54 & $58.50 \pm 0.27$ & $5.44 \pm 0.11$ & $2.10 \pm 0.11$ & 0.995 & 2.01 \\
\hline $40: 60$ & $64.05 \pm 1.13$ & $0.096 \pm 0.004$ & 0.971 & 9.96 & $57.51 \pm 0.28$ & $5.10 \pm 0.11$ & $1.13 \pm 0.12$ & 0.994 & 2.14 \\
\hline $20: 80$ & $63.82 \pm 0.88$ & $0.125 \pm 0.005$ & 0.967 & 11.76 & $59.32 \pm 0.17$ & $6.78 \pm 0.11$ & $1.25 \pm 0.07$ & 0.997 & 1.13 \\
\hline $0: 100$ & $42.45 \pm 2.02$ & $0.066 \pm 0.006$ & 0.933 & 9.71 & $33.10 \pm 0.20$ & $3.54 \pm 0.10$ & $3.33 \pm 0.14$ & 0.991 & 1.27 \\
\hline
\end{tabular}

$\mathrm{BMP}_{\text {max }}\left(\mathrm{mL} \mathrm{CH}_{4} \mathrm{~g} \mathrm{VS}^{-1}\right) ; \mathrm{R}_{\text {max }}\left(\mathrm{mL} \mathrm{CH}_{4} \mathrm{~d}^{-1} \mathrm{~g} \mathrm{VS}^{-1}\right)$. 
Table 7. Kinetic parameters for FW:SM ratios under the NN condition.

\begin{tabular}{|c|c|c|c|c|c|c|c|c|c|}
\hline \multirow{2}{*}{$\begin{array}{c}\text { FW:SM } \\
\text { Ratio }\end{array}$} & \multicolumn{4}{|c|}{ First-order Kinetics Model } & \multicolumn{5}{|c|}{ Modified Gompertz Model } \\
\hline & $\mathbf{B M P}_{\max }$ & $\begin{array}{c}\mathbf{k}_{\mathbf{h}} \\
\left(\mathbf{d}^{-1}\right)\end{array}$ & $\mathbf{R}^{2}$ & MSE & $\mathbf{B M P}_{\max }$ & $\mathbf{R}_{\max }$ & $\begin{array}{c}\lambda \\
\text { (d) }\end{array}$ & $\mathbf{R}^{2}$ & MSE \\
\hline $100: 0$ & $62.46 \pm 1.89$ & $0.084 \pm 0.006$ & 0.945 & 18.90 & $53.63 \pm 0.32$ & $5.35 \pm 0.15$ & $2.28 \pm 0.14$ & 0.991 & 3.12 \\
\hline $80: 20$ & $54.84 \pm 0.88$ & $0.099 \pm 0.004$ & 0.974 & 6.62 & $49.38 \pm 0.25$ & $4.49 \pm 0.10$ & $1.06 \pm 0.12$ & 0.993 & 1.79 \\
\hline $60: 40$ & $76.10 \pm 2.75$ & $0.070 \pm 0.005$ & 0.952 & 22.09 & $62.17 \pm 0.32$ & $5.43 \pm 0.11$ & $2.36 \pm 0.12$ & 0.995 & 2.44 \\
\hline $50: 50$ & $63.57 \pm 2.08$ & $0.072 \pm 0.005$ & 0.957 & 13.92 & $52.38 \pm 0.24$ & $4.60 \pm 0.08$ & $2.21 \pm 0.10$ & 0.996 & 1.36 \\
\hline $40: 60$ & $71.32 \pm 2.97$ & $0.064 \pm 0.005$ & 0.950 & 19.83 & $56.62 \pm 0.30$ & $4.90 \pm 0.10$ & $2.58 \pm 0.12$ & 0.995 & 2.08 \\
\hline $20: 80$ & $56.12 \pm 1.80$ & $0.088 \pm 0.007$ & 0.933 & 19.72 & $48.15 \pm 0.14$ & $5.74 \pm 0.09$ & $2.81 \pm 0.07$ & 0.997 & 0.73 \\
\hline $0: 100$ & $34.85 \pm 1.65$ & $0.056 \pm 0.005$ & 0.952 & 3.84 & $26.54 \pm 0.31$ & $1.95 \pm 0.07$ & $2.04 \pm 0.24$ & 0.980 & 1.58 \\
\hline
\end{tabular}

$\mathrm{BMP}_{\text {max }}\left(\mathrm{mL} \mathrm{CH}_{4} \mathrm{~g} \mathrm{VS}^{-1}\right) ; \mathrm{R}_{\text {max }}\left(\mathrm{mL} \mathrm{CH}_{4} \mathrm{~d}^{-1} \mathrm{~g} \mathrm{VS}^{-1}\right)$.

Tables 6 and 7 show that for both nutrient conditions (WN and NN), the values of $\mathrm{R}^{2}$ and MSE indicated a better adjustment to the modified Gompertz model $\left(\mathrm{R}^{2}>0.98\right.$ and $\left.\mathrm{MSE}<8\right)$. Additionally, it was noted that the hydrolysis constant $\left(\mathrm{k}_{\mathrm{h}}\right)$ of $\mathrm{FW}$ was higher than that of SM. Therefore, the incorporation of SM did not produce an increase in the value of $\mathrm{k}_{\mathrm{h}}$ or a reduction in $\lambda$. This may be due to the presence of lignocellulosic matter in SM, known by its slow degradation (Pavlostathis and Giraldo-Gomez, 1991). In addition, the lower degradation rate of SM can be related to the predominance of particulate organic matter. This is consistent with the findings of Bouallagui et al. (2005), who indicated there is an inversely proportional relationship between the degradation rate of the substrates and their particulate organic matter content.

\section{CONCLUSIONS}

FW has a potential for use by means of $\mathrm{AD}$, given the high organic matter and moisture content of the waste. However, the low pH of FW, the lack of bicarbonate alkalinity and its phosphorus deficiency affect $\mathrm{CH}_{4}$ production and the stability of the process. One strategy to improve such deficiencies in $\mathrm{AD}$ of FW is the AcoD with waste that has complementary characteristics, such as SM, which can provide phosphorus and buffering capacity of the process.

The AcoD of FW with SM improved the BMP of FW; the highest value was obtained for the FW:SM 60:40 ratio under the $\mathrm{WN}$ condition $\left(72.87 \mathrm{~mL} \mathrm{CH}_{4}\right.$ $\left.\mathrm{g} \mathrm{VS}^{-1}\right)$. This represented a $27 \%$ increase in BMP in comparison with the AD of the unmixed FW. In general, the BMP was higher under the $\mathrm{WN}$ condition and presented synergistic effects that were observed by the increase in $\mathrm{CH}_{4}$ production, the contribution of phosphorus and essential micronutrients and the improvement of the stability of the process.

The experimental results showed better adjustment to the modified Gompertz model, which took the lag phase $(\lambda)$ into consideration. In this study, the addition of SM to FW did not favor hydrolysis because this did not cause an increase in the rate of degradation $\left(\mathrm{k}_{\mathrm{h}}\right)$ or a reduction in the lag phase in comparison with the $\mathrm{AD}$ of the unmixed FW.

\section{ACKNOWLEDGEMENTS}

The authors would like to thank the Universidad del Valle for the financial support of the research projects C.I-2890 and 2962.

\section{NOMENCLATURE}

$\alpha$ index Alpha index (BA/TA)

$\lambda \quad$ Lag phase

AD Anaerobic digestion

AcoD Anaerobic co-digestion

BA Bicarbonate alkalinity

BMP Biochemical Methane Potential

$\mathrm{BMP}_{\mathrm{w}}$ Weighted Biochemical Methane Potential

FW Food Waste

$\mathrm{k}_{\mathrm{h}} \quad$ First-order hydrolysis constant

MSE Mean squared error

NN Without nutrients

S.D. Standard deviation

SM Swine manure

TA Total alkalinity

WN With nutrients

WWTP Wastewater treatment plant

\section{REFERENCES}

Adelard, L., Poulsen, T. G. and Rakotoniaina, V. Biogas and methane yield in response to co-and separate digestion of biomass wastes. Waste Management \& Research 33(1), 55-62 (2015).

Angelidaki, I., Alves, M., Bolzonella, D., Borzacconi, L., Campos, J., Guwy, A., Kalyuzhnyi, S., Jenicek, P. and Van Lier, J. Defining the biomethane potential (BMP) of solid organic wastes and energy crops: a proposed protocol for batch assays. Water Science and Technology 59(5), 927-934 (2009). 
APHA, AWWA and WEF. Standard methods for examination of water and wastewater. A. W. W. A. American Water Works Association and Water Environment Federation, Water Environment Federation. Washington D.C. (2012).

Aquino, S. F., Chernicharo, C. A., Foresti, E., Santos, M. d. L. F. d. and Monteggia, L. O. Metodologias para determinação da atividade metanogênica específica (AME) em lodos anaeróbios. Eng. Sanit. Ambient 12(2), 192-201 (2007).

Banks, C. J., Zhang, Y., Jiang, Y. and Heaven, S. Trace element requirements for stable food waste digestion at elevated ammonia concentrations. Bioresource Technology 104, 127-135 (2012).

Bouallagui, H., Touhami, Y., Cheikh, R. B. and Hamdi, $\mathrm{M}$. Bioreactor performance in anaerobic digestion of fruit and vegetable wastes. Process Biochemistry 40(3), 989-995 (2005).

Browne, J. D., Allen, E. and Murphy, J. D. Evaluation of the biomethane potential from multiple waste streams for a proposed community scale anaerobic digester. Environmental Technology 34(13-14), 2027-2038 (2013).

Cabbai, V., Ballico, M., Aneggi, E. and Goi, D. BMP tests of source selected OFMSW to evaluate anaerobic codigestion with sewage sludge. Waste Management 33(7), 1626-32 (2013).

Campos, E. Optimización de la digestión anaerobia de purines de cerdo mediante codigestión con residuos orgánicos de la industria agroalimentaria. Tesis doctoral Universidad de Lleida (2001).

Chen, H., Jiang, W., Yang, Y., Yang, Y. and Man, $X$. State of the art on food waste research: a bibliometrics study from 1997 to 2014. Journal of Cleaner Production 140, Part 2, 840-846 (2017).

Chu, C.-F., Li, Y.-Y., Xu, K.-Q., Ebie, Y., Inamori, Y. and Kong, H.-N. A pH-and temperature-phased two-stage process for hydrogen and methane production from food waste. International Journal of Hydrogen Energy 33(18), 4739-4746 (2008).

Facchin, V., Cavinato, C., Fatone, F., Pavan, P., Cecchi, F. and Bolzonella, D. Effect of trace element supplementation on the mesophilic anaerobic digestion of foodwaste in batch trials: The influence of inoculum origin. Biochemical Engineering Journal 70, 71-77 (2013).

FAO. Global food losses and food waste - Extent, causes and prevention. Rome (2011).

Flotats, X., Campos, E., Palatsi, J. and Bonmatí, $\mathrm{X}$. Digestión anaerobia de purines de cerdo $\mathrm{y}$ codigestión con residuos de la industria alimentaria. Porci 65, 51-65 (2001).

ICONTEC. Norma Técnica Colombiana 1369. Determinación por absorción atómica de los elementos secundarios y menores en fertilizantes sólidos y líquidos. Colombia (2009).
ICONTEC. Norma Técnica Colombiana 5167. Productos para la industria agrícola, productos orgánicos usados como abonos o fertilizantes y enmiendas de suelo. Colombia (2011).

Kafle, G. K. and Kim, S. H. Anaerobic treatment of apple waste with swine manure for biogas production: batch and continuous operation. Applied Energy 103, 61-72 (2013).

Khanal, S. K. Anaerobic biotechnology for bioenergy production: principles and applications, John Wiley \& Sons (2011).

Koch, K. y Drewes, J. E. Alternative approach to estimate the hydrolysis rate constant of particulate material from batch data. Applied Energy 120: 1115 (2014).

Labatut, R. and Gooch, C. Monitoring of anaerobic digestion process to optimize performance and prevent system failure. Proceedings of Got Manure? Enhancing Environmental and Economic Sustainability, 209-225 (2012).

Labatut, R. A., Angenent, L. T. and Scott, N. R. Biochemical methane potential and biodegradability of complex organic substrates. Bioresource Technology 102(3), 2255-2264 (2011).

Lima, D., Rodrigues, J., Boe, K., Alvarado-Morales, M., Ellegaard, L. and Angelidaki, I. Anaerobic modeling for improving synergy and robustness of a manure co-digestion process. Brazilian Journal of Chemical Engineering 33(4), 871-883 (2016).

Lü, F., Hao, L., Zhu, M., Shao, L. and He, P. Initiating methanogenesis of vegetable waste at low inoculum-to-substrate ratio: Importance of spatial separation. Bioresource Technology 105, 169-173 (2012).

MacLeod, M., Gerber, P., Mottet, A., Tempio, G., Falcucci, A., Opio, C., Vellinga, T., Henderson, B. \& Steinfeld, H. Greenhouse gas emissions from pig and chicken supply chains - A global life cycle assessment. Food and Agriculture Organization of the United Nations (FAO), Rome (2013).

Mata-Alvarez, J., Dosta, J., Romero-Güiza, M. S., Fonoll, X., Peces, M. and Astals, S. A critical review on anaerobic co-digestion achievements between 2010 and 2013. Renewable and Sustainable Energy Reviews 36, 412-427 (2014).

Matheri, A. N., Belaid, M., Seodigeng, T. and Ngila, J. C. The Role of Trace Elements on Anaerobic Codigestion in Biogas Production. Proceedings of the World Congress on Engineering (2016).

Moestedt, J., Nordell, E., Yekta, S. S., Lundgren, J., Marti, M., Sundberg, C., Ejlertsson, J., Svensson, B. H. and Björn, A. Effects of trace element addition on process stability during anaerobic codigestion of OFMSW and slaughterhouse waste. Waste Management 47, 11-20 (2016). 
Nielfa, A., Cano, R. and Fdz-Polanco, M. Theoretical methane production generated by the co-digestion of organic fraction municipal solid waste and biological sludge. Biotechnology Reports 5, 14-21 (2015).

Nordell, E., Nilsson, B., Nilsson Påledal, S., Karisalmi, K. y Moestedt, J.. Co-digestion of manure and industrial waste - The effects of trace element addition. Waste Management 47, Part A: 21-27 (2016).

Oviedo-Ocaña, E. R., Torres-Lozada, P., MarmolejoRebellon, L. F., Torres-López, W. A., Dominguez, I., Komilis, D., and Sánchez, A. A systematic approach to evaluate parameter consistency in the inlet stream of source separated biowaste composting facilities: A case study in Colombia. Waste Management 62, 24-32 (2017).

Owen, W., Stuckey, D., Healy, J., Young, L. and McCarty, P. Bioassay for monitoring biochemical methane potential and anaerobic toxicity. Water Research 13(6), 485-492 (1979).

Pabón, C., Castanares, G. and Van Lier, J. An OxiTop ${ }^{\circledR}$ protocol for screening plant material for its biochemical methane potential (BMP). Water Science \& Technology 66(7), 1416-1423 (2012).

Pagés, J., Pereda, I., Lundin, M. and Sárvári, I. Co-digestion of different waste mixtures from agro-industrial activities: Kinetic evaluation and synergetic effects. Bioresource Technology 102(23), 10834-10840 (2011).

Parra, B., Torres, P., Marmolejo, L., Cárdenas, L., Vásquez, C., Torres, W. and Ordoñez, J. Efecto de la Relación Sustrato-Inóculo sobre el Potencial Bioquímico de Metano de Biorresiduos de Origen Municipal. Ingeniería Investigación y Tecnología XVI(4), 515-526 (2015).

Parra-Orobio, B. A., Donoso-Bravo, A., Ruiz-Sánchez, J. C., Valencia-Molina, K. J., and Torres-Lozada, P. Effect of inoculum on the anaerobic digestion of food waste accounting for the concentration of trace elements. Waste Management (71), 342-349 (2018).

Pavlostathis, S. and Giraldo $\square$ Gomez, E. Kinetics of anaerobic treatment: a critical review. Critical Reviews in Environmental Science and Technology 21(5-6), 411-490 (1991).

Pérez, A. and Torres, P. Índices de alcalinidad para el control del tratamiento anaerobio de aguas residuales fácilmente acidificables. Ingeniería y Competitividad 10(2), 41-52 (2011).

Raposo, F., Banks, C. J., Siegert, I., Heaven, S. and Borja, R. Influence of inoculum to substrate ratio on the biochemical methane potential of maize in batch tests. Process Biochemistry 41, 1444-1450 (2006).

Raposo, F., De La Rubia, M. A., Fernández-Cegrí, V. and Borja, R. Anaerobic digestion of solid organic substrates in batch mode: An overview relating to methane yields and experimental procedures. Renewable and Sustainable Energy Reviews 16(1), 861-877 (2012).
Rodriguez-Verde, I., Regueiro, L., Carballa, M., Hospido, A. and Lema, J. M. Assessing anaerobic co-digestion of pig manure with agroindustrial wastes: the link between environmental impacts and operational parameters. Sci Total Environ 497498, 475-83 (2014).

Romero-Güiza, M., Vila, J., Mata-Alvarez, J., Chimenos, J. and Astals, S. The role of additives on anaerobic digestion: A review. Renewable and Sustainable Energy Reviews 58, 1486-1499 (2016).

Schirmer, W., Jucá, J., Schuler, A., Holanda, S. and Jesus, L. Methane production in anaerobic digestion of organic waste from Recife (Brazil) landfill: evaluation in refuse of diferent ages. Brazilian Journal of Chemical Engineering 31(2), 373-384 (2014).

Sitorus, B., Sukandar and Panjaitan, S. D. Biogas recovery from anaerobic digestion process of mixed fruit -vegetable wastes. Energy Procedia 32, 176-182 (2013).

Soto, M., Méndez, R. and Lema, J. M. Methanogenic and non-methanogenic activity tests. Theoretical basis and experimental set up. Water Research 27(8), 1361-1376 (1993).

Thi, N. B. D., Kumar, G. and Lin, C.-Y. An overview of food waste management in developing countries: current status and future perspective. Journal of environmental management 157, 220-229 (2015).

Tian, H., Duan, N., Lin, C., Li, X. and Zhong, M. Anaerobic co-digestion of kitchen waste and pig manure with different mixing ratios. J Biosci Bioeng 120(1), 51-7 (2015).

Torres, P. and Pérez, A. Actividad Metanogénica Específica: una herramienta de control y optimización de sistemas de tratamiento anaerobio de aguas residuales. Ingeniería de Recursos Naturales y del Ambiente 9(9), 5-14 (2010).

Uemura, S. Mineral requirements for mesophilic and thermophilic anaerobic digestion of organic solid waste. Int. J. Environ. Res 4, 33-40 (2010).

Wang, Y., Zhang, Y., Wang, J. and Meng, L. Effects of volatile fatty acid concentrations on methane yield and methanogenic bacteria. Biomass and Bioenergy 33(5), 848-853 (2009).

Ye, J., Li, D., Sun, Y., Wang, G., Yuan, Z., Zhen, F. and Wang, Y. Improved biogas production from rice straw by co-digestion with kitchen waste and pig manure. Waste Management 33(12), 2653-8 (2013).

Ye, Y., Zamalloa, C., Lin, H., Yan, M., Schmidt, D. and $\mathrm{Hu}, \mathrm{B}$. Evaluation of anaerobic co-digestion of dairy manure with food wastes via bio-methane potential assay and CSTR reactor. Journal of Environmental Science and Health, Part B 50(3), 217-227 (2015). 
Zhang, R., El-Mashad, H. M., Hartman, K., Wang, F., Liu, G., Choate, C. and Gamble, P. Characterization of food waste as feedstock for anaerobic digestion. Bioresource Technology 98(4), 929-935 (2007).
Zhang, L., Ouyang, W. and Lia, A. Essential role of trace elements in continuous anaerobic digestion of food waste. Procedia Environmental Sciences 16, 102-111 (2012). 
